\title{
New records of trypanorhynch cestodes from the Gulf of Mexico, including Kotorella pronosoma (Stossich, 1901) and Heteronybelinia palliata (Linton, 1924) comb. n.
}

\author{
Harry W. Palm ${ }^{1}$ and Robin M. Overstreet ${ }^{2}$ \\ ${ }^{1}$ Marine Pathology Group, Abteilung Fischereibiologie, Institut für Meereskunde an der Universität Kiel, Düsternbrooker Weg \\ 20, D-24105 Kiel, Germany; \\ ${ }^{2}$ Gulf Coast Research Laboratory, The University of Southern Mississippi, P.O. Box 7000, Ocean Springs, Mississippi 39566- \\ 7000, USA
}

Key words: Cestoda, Dasyrhynchus, Heteronybelinia, Kotorella, Nybelinia, Gulf of Mexico, taxonomy, trypanorhynch, zoogeographical distribution

\begin{abstract}
Four trypanorhynchs, Kotorella pronosoma (Stossich, 1901), Nybelinia cf. bisulcata (Linton, 1889), Nybelinia scoliodoni (Vijayalakshmi, Vijayalakshmi et Gangadharam, 1996), and Dasyrhynchus pacificus Robinson, 1965 are reported for the first time from the Gulf, which is now known to harbour at least 34 different species. In addition to the range extension for the trypanorhynchs listed above, 21 new host records are reported involving 13 cestode species. Characters of the genus Kotorella Euzet et Radujkovic, 1989 are emended, Nybelinia narinari MacCallum, 1917 is considered a junior synonym of Kotorella pronosoma (Stossich, 1901), and Heteronybelinia palliata (Linton, 1924) comb. $\mathrm{n}$. is redescribed. The usefulness of the bulb ratio as a means to distinguish different tentaculariid species is discussed, and the importance of shallow water localities for the life cycle of trypanorhynch cestodes is emphasised.
\end{abstract}

The Gulf of Mexico is well known as a locality for many different trypanorhynch cestodes, both as metacestodes in invertebrates and teleosts and as adults in elasmobranchs. All superfamilies and most of the families recognised by Campbell and Beveridge (1994) and Palm $(1995,1997 \mathrm{a})$ are represented. Accepted species reported from the Gulf to date are Eutetrarhynchus lineatus (Linton, 1909), Oncomegas wageneri (Linton, 1890), Parachristianella dimegacantha Kruse, 1959, P. heteromegacantha Feigenbaum, 1975, P. monomegacantha Kruse, 1959, Prochristianella hispida (Linton, 1890), $P$. tenuispine (Linton, 1890), Trimacracanthus binuncus (Linton, 1909), Diplootobothrium springeri Chandler, 1942, Otobothrium cysticum (Mayer, 1842), O. insigne Linton, 1905, O. penetrans Linton, 1907, Pseudotobothrium dipsacum (Linton, 1897), Poecilancistrum caryophyllum (Diesing, 1850), Hepatoxylon megacephalum (Rudolphi, 1819), Heteronybelinia estigmena (Dollfus, 1960), H. palliata (Linton, 1924), Nybelinia lingualis (Cuvier, 1817), Sphyriocephalus sp., Tentacularia coryphaenae Bosc, 1797, Callitetrarhynchus gracilis (Rudolphi, 1819), Dasyrhynchus giganteus (Diesing, 1850), Grillotia perelica Shuler, 1938, G. similis (Linton, 1900), G. heptanchi-group of Chandler (1954), Pseudogrillotia pleistacantha Dollfus, 1969, P. zerbiae Palm, 1995, Gymnorhynchus gigas (Cuvier, 1817), Pterobothrium heteracanthum (Diesing, 1850) and $P$. lintoni (MacCallum, 1916) (see Chandler 1954, Kruse 1959, Thatcher 1961, Aldrich 1965, Schlicht and
McFarland 1967, Nikolaeva and Paruhin 1968, Dollfus 1969, Henson 1975, Overstreet 1977, 1978b, Hildreth and Lumsden 1985, Palm 1995, Palm and Overstreet 2000). Metacestodes of a few other trypanorhynch species require confirmation or identification (e.g. Feigenbaum 1975, Cake 1977). Thus, the Gulf of Mexico constitutes one of the best-studied regions for these marine parasites.

Within the present study, a variety of trypanorhynch species from the Gulf of Mexico was identified. Most of the specimens are plerocercoids from teleosts, but we are including some records of adults from the blacktip shark, Carcharhinus limbatus (Valenciennes). New records allow observations on zoogeographical distribution as well as intraspecific variability. Palm and Overstreet (2000) proposed the shallow waters in the Gulf of Mexico to be important in the life cycle of Otobothrium cysticum. The importance of shallow waters for the life cycle of other trypanorhynch species reported from the region will also be discussed. Finally, the identity of Nybelinia narinari is clarified, and Heteronybelinia palliata comb. n. is redescribed.

\section{MATERIALS AND METHODS}

From June to July 1993, a sample of teleost and elasmobranch species from the Gulf of Mexico was examined for trypanorhynch cestodes by both authors, and, since 1969 , other collections have been made by the junior author. Many of the fish were obtained with the help of small recreational and Gulf 
Coast Research Laboratory vessels. Standard measurements and drawings were made using a Leitz Wetzlar Orthoplan microscope. Drawings were made using a Leitz Wetzlar Dialux 22 microscope with a drawing tube. To clarify the identity of some tentaculariids, we borrowed type material of Nybelinia narinari and $N$. palliata as well as material deposited as $N$. bisulcata from the U.S. National Parasite Collection, Beltsville (USNPC).

Measurements were taken on the following features: scolex length (SL), scolex width at level of pars bothridialis (SW), pars bothridialis (pbo), pars vaginalis (pv), pars bulbosa (pb), pars postbulbosa (ppb), velum (vel), appendix (app), bulb length (BL), bulb width (BW), bulb length to width ratio (BR), proportions of pbo : pv : pb (SP), tentacle width (TW) and tentacle sheath width (TSW). If possible, the tentacle length (TL) was estimated. Additionally, the tentacular armature was described as follows: armature homeomorphous or heteromorphous, hooks per half spiral row (hsr), total hook length (L), hook height $(\mathrm{H})$ and the total length of the base (B).

All measurements are given in micrometres unless otherwise indicated. Illustrations are provided where useful; otherwise, the reader is referred to illustrations of other authors. The classification follows that of Palm (1995, 1997a), and orientation of tentacle surfaces follows that of Campbell and Beveridge (1994).

\section{RESULTS}

Superfamily TenTACULARIOIDEA Poche, 1926

Family T e n t a c u l a r i i d a e Poche, 1926

Kotorella pronosoma (Stossich, 1901)

Figs. 1, 2

New synonymy: Nybelinia narinari (MacCallum, 1917)

Supplemental data (based on one adult specimen labelled as "type" of Nybelinia narinari MacCallum, 1917, USNPC 35813, G.A. MacCallum coll., 25.5.1916, from the spiral valve of Aetobatis narinari Euphrasen, Java, Jakarta (=Batavia), Java Sea, Indonesia): Scolex craspedote, 985 SL, $400 \mathrm{SW}$; bothridia 4, widely spaced, lateral margins free, longer than half scolex length, width $120-135$, posterior portion of bothridia 280 wide, not attached to scolex peduncle, marginal band of hookshaped microtriches in "V- shaped" pattern with apex of $\mathrm{V}$ pointing anteriorly; pbo 430; pv 540; pb 135; vel 250280; BL 132 (130-135); BW 68 (67-70); BR 1.9:1; SP 3.2:4.1:1. Tentacles emerging pairwise, 290 long, slender, diminishing in size toward tip; TW 25 (basal) and 17 (apical); basal tentacular swelling lacking. Tentacle sheaths straight; TSW 13-17. Prebulbular organs lacking, muscular rings around basal part of tentacle sheath not visible. Retractor muscles originating in basal part of bulbs. Armature homeoacanthous, heteromorphous; tentacular hooks on antibothridial tentacle surface increasing in size toward distal portion of tentacle, slender, spiniform, without enlarged basal plates, more widely spaced than on bothridial surface; tentacular hooks on bothridial surface similar in size along tentacle, tightly packed, having broad diamond-shaped basal plate, with
9-10 L and 7-8 B, with distance between hooks larger toward apical part of tentacle; basal hooks 4-6 L, 2-4 B, 8 hsr; metabasal hooks 9-10 L, 2-3 B, 6-7 hsr. Strobila acraspedote, 300 wide, consisting of 46 proglottids, with last 6 proglottids longer (320) than wide (300, last proglottid). Testes spherical, 23-30 in diameter; other internal structures not seen.

Supplemental data (based on two postlarvae from Cynoscion nebulosus (Cuvier), Figs. 1, 2): Scolex as indicated above, 675 (670-680) SL (with appendix), 285 (270-300) SW, with posterior part 255 (240-270) wide and not attached to scolex peduncle (Fig. 2). Bothridia more than half length of scolex, 125 (120-130) wide; bothridial margins covered with band of microtriches in V-shaped pattern as reported for adult, 400 (370-430) pbo, 430 (420-440) pv, 108 (106-110) pb, 63 (60-66) vel, 173 (160-186) app, 96 (91-101) and 99 (88-101) BL, 56 (5359) and 57 (56-59) BW; BR 1.7:1; SP 3.8:4:1 (3.7:4:13.9:4:1). Tentacles short, 225 (200-250), 25 TW (basal), 17 TW (apical); basal tentacular swelling lacking; tentacular sheaths straight, 15-17 TSW. Armature with 8-10 L, 5.0-7.5 B (basal and metabasal; bothridial surface), with 3-5 L, 1.5-2.0 B (basal; antibothridial surface), with 9-11 L, 2.0-2.5 B (metabasal; antibothridial surface); hsr 8-9 (basal), 6-7 (metabasal).

$\mathrm{H}$ o s t : Cynoscion nebulosus (Cuvier), spotted seatrout (Sciaenidae).

S i t e : Stomach wall.

L o c a 1 i t y : Coastal waters off Ocean Springs, Mississippi, Gulf of Mexico.

Remarks: We consider Nybelinia narinari MacCallum, 1917 to be a junior subjective synonym of Kotorella pronosoma (Stossich, 1901). Euzet and Radujkovic (1989) redescribed Rhynchobothrium pronosomum Stossich, 1901 as $K$. pronosoma from the spiral valve of Dasyatis pastinaca (Linnaeus) from the Mediterranean Sea (Adriatic Sea). Our measurements, including those of material labelled as "type" of N. narinari, correspond with those provided by Euzet and Radujkovic (1989), especially the values for SL, pb, BL, BW, and TL. Also, hook sizes of the tentacular armature described by Euzet and Radujkovic (1989), Campbell and Beveridge (1994) and Palm and Walter (1999) are similar $(\mathrm{L}=8-11 \mu \mathrm{m}$ in the present study compared to $10-15$ as summarised in Palm and Walter 1999). The scolex of K. pronosoma (as $N$. narinari) was well illustrated by MacCallum (1917, fig. 22), however, lacking a detailed description of the armature. The present description adds that the bothridia are widely spaced with free lateral margins, a character distinguishing the genus Kotorella from Nybelinia. The type specimen of $N$. narinari MacCallum, 1917 (=K. pronosoma) is mounted together with the type specimen of Taenia narinari MacCallum, 1917 on the same slide.

Our material of postlarvae obtained from a $17-\mathrm{cm}$ long spotted seatrout Cynoscion nebulosus from the Gulf of Mexico also corresponds with the type material of 

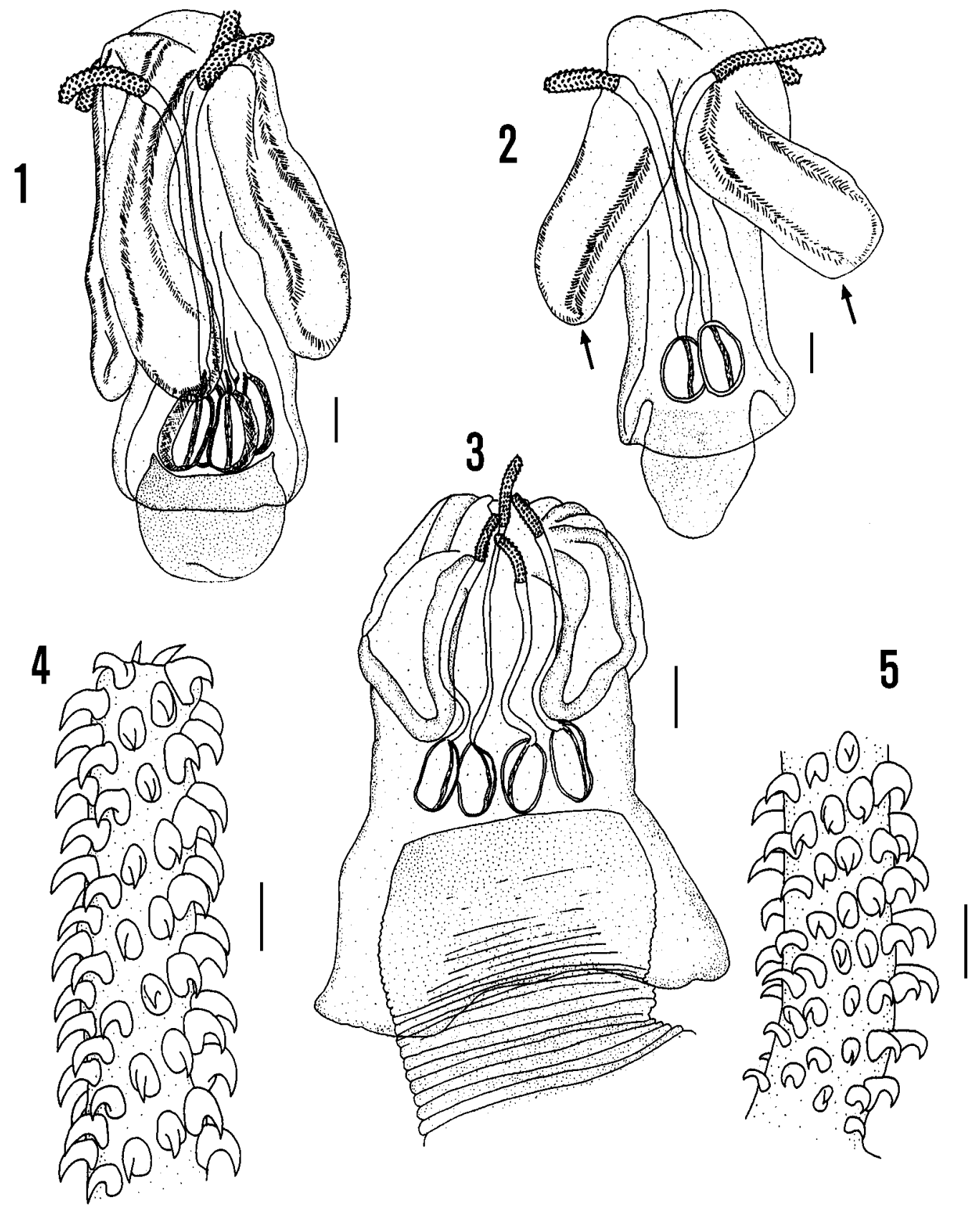

Figs. 1-2. Two different postlarvae of Kotorella pronosoma from Cynoscion nebulosus. Note the free posterior margins of the bothridia (arrow), clearly visible in the specimen in Fig. 2. Figs. 3-5. Heteronybelinia palliata. Fig. 3. Scolex isolated from Sphyrna zygaena. Fig. 4. Metabasal armature. Fig. 5. Basal armature. Scale bars: Figs. $1,2=50 \mu \mathrm{m}$; Fig. $3=200 \mu \mathrm{m}$; Figs. $4,5=20 \mu \mathrm{m}$.

Nybelinia herdmani (Shipley et Hornell, 1906), a species recently redescribed and considered to be a junior synonym of K. pronosoma by Palm and Walter (1999) on the basis of comparable bulb ratio, scolex proportions and form and arrangement of the tentacular armature. Even though the size of the scolex and the 8-11 $\mu \mathrm{m}$ tentacular hooks are smaller than the 13-15 $\mu \mathrm{m}$ ones reported by Palm and Walter (1999), they are of similar form and arrangement as those from the type specimen of $N$. herdmani as illustrated in Palm and Walter (1999, figs 8ab). Thus, the present findings underline the synonymy of $N$. herdmani with $K$. pronosoma.

As described for adults of $K$. pronosoma, the present postlarvae possess long and slender bothridia with free lateral margins and characteristic marginal, hook-like microtriches in a V-shaped pattern, as can be seen under 
the light microscope (Figs. 1, 2). The occurrence and arrangement of such microtriches closely resemble those described from the bothridial margins of Tentacularia coryphaenae and three species of Nybelinia reported by Palm (1995). This finding might support a close phylogenetic relationship between Kotorella and Nybelinia as proposed by Campbell and Beveridge (1994) and Palm (1995, 1997a). However, the free posterior margins of the bothridia of $K$. pronosoma are unique within Tentac-ulariidae, supporting recognition of the genus Kotorella. This feature of the posterior margins should be added to the generic diagnoses by Euzet and Radujkovic (1989) and by Campbell and Beveridge (1994) as the emendation "Posterior portions of bothridia free and not fused with pedunculus scolices."

Postlarvae of $K$. pronosoma are recorded for the first time, from the teleost $C$. nebulosus. This finding represents a new host record and extends the known range of distribution for the species from the Mediterranean Sea and the Indian Ocean to the Western Atlantic region. Kotorella pronosoma can be considered a cosmopolitan species, with a distribution pattern similar to that of several other tentaculariid cestodes.

Nybelinia scoliodoni (Vijayalakshmi, Vijayalakshmi et Gangadharam, 1996)

Supplemental data (based on measurements of three postlarvae): Scolex 1230 (1087-1367) SL, 845 (834-867) SW, 671 (647-713) pbo, 329 (300-387) pv, 310 (294-320) pb, 47 (30-70) ppb, 510 (467-567) vel, 540 (400-634) app, 308 (300-320) BL, 110 (105-120) BW; BR 2.8:1 (2.62.9:1); SP 2.2:1.1:1. Tentacles 450-459 long (when about half still invaginated), basal tentacle swelling lacking; TW 28-37; tentacle sheaths sinuous, with 1-2 spirals (25-33 TSW); prebulbular organs and muscular rings around basal part of tentacle sheaths absent. Retractor muscles originating in basal part of bulbs. Metabasal armature homeoacanthous, homeomorphous, with characteristic basal armature, with hsr 4-5; basal armature consisting of about 11 rows, with compact rosethorn-shaped hooks, with hsr 6-7; hooks increasing in size; hooks in rows 1-5: 4.8-7.0 L, 4.8-6.3 B; hooks in rows 6-11: 9-11 L, 7-10 B; hooks in rows 12-14 changing to long and spiniform (22$25 \mathrm{~L})$, with small basal plate (6.5-8.5 B).

$\mathrm{H}$ o s t : Coryphaena hippurus Linnaeus, common dolphin fish (Coryphaenidae).

$\mathrm{S}$ i t e : Postlarvae migrating out of the stomach wall.

L o c a 1 i t y : Coastal waters off Ocean Springs, Mississippi, Gulf of Mexico.

Remarks: More than one hundred postlarvae were found in the stomach of a 131-cm long female of Coryphaena hippurus from waters off Ocean Springs. The postlarvae actively penetrated the stomach wall about one hour after the fish was dissected, which was several hours after the fish had been caught and kept on ice.
Even though scolex measurements of the present specimens are twice as large as those given for $N$. scoliodoni in the original description and by Palm (1999), the tentacular armature is identical to that described by Vijayalakshmi et al. (1996) and Palm (1999, fig. 17). The change in form from rosethorn-shaped basal to spiniform metabasal hooks is unique within the genus. Having a larger scolex, the present specimens also have basal hooks that are slightly larger (hooks in rows $1-5: 4.8-7.0$ versus 3.5-5.6 L, 4.8-6.3 versus 3.5-4.9 $\mathrm{B}$; in rows 6-11: 9-11 versus 7-9.8 L, 7-10 versus 5.6-8.4 B; hooks in rows 1214: 22-25 versus 22-26 L, 6.5-8.5 versus 7.7-10.5 B) than those described by Palm (1999). However, Vijayalakshmi et al. (1996) reported a hook size of 8-11 for the rosethornshaped hooks, similar to the measurements of hooks in rows 6-11, and they also demonstrated more minute hooks in the basal part of the tentacle similar to those in rows 1-5 of the present specimens. The known range of distribution for the species is extended to the Gulf of Mexico, and Coryphaena hippurus represents a new host record.

\section{Heteronybelinia cf. estigmena (Dollfus, 1960)}

Supplemental data (based on one postlarva): Scolex with $2050 \mathrm{SL}, 1235 \mathrm{SW}, 1370$ pbo, $967 \mathrm{pv}, 435 \mathrm{pb}, 0$ ppb, 367 vel, 634 app; BL 384 (360-400); BW 119 (115-120); BR 3.2:1; SP 3.1:2.2:1. Tentacles 660 long, without basal tentacle swelling; TW 40-48; tentacle sheaths straight (3743 TSW), with muscular rings around basal part of tentacle sheaths; prebulbular organs absent. Retractor muscles originating in basal part of bulb. Metabasal armature homeoacanthous, heteromorphous, without characteristic basal armature; metabasal armature consisting of rosethorn-shaped hooks on both bothridial and antibothridial portions; bothridial portion with 13-14 L, 12.5-13.3 B, 11.8-12 H; antibothridial portion 10-11.5 L, 10.5-11.8 B, 9.5-9.7 H; hooks decreasing slightly in size toward basal part of tentacle; hooks on bothridial portion 10-11.5 L, 10.5-11.8 B, 10.3-10.3 H; hooks on antibothridial portion 9.7-10.5 L, 9.7-10.5 B, 8.8-9.2 H; hsr 6-7.

$\mathrm{H}$ o s $\mathrm{t}$ : Thunnus albacares (Bonnaterre), yellowfin tuna (Scombridae).

$\mathrm{S}$ i t e : Stomach wall.

L o c a 1 i t y : Coastal waters off Ocean Springs, Mississippi, Gulf of Mexico.

Remarks: The present specimen from a $137-\mathrm{cm}$ long female yellowfin tuna clearly belongs to subgroup IIAa in Palm et al. (1997). However, the morphometrical data do not correspond directly with any particular species. The species shows similarities with Heteronybelinia estigmena of Dollfus (1960) (see Palm 1999). With a total length of about $2 \mathrm{~mm}$ and hooks up to $14 \mu \mathrm{m}$, the species appears slightly larger than $H$. estigmena $(1 \mathrm{~mm} \mathrm{SL}$, bothridial hooks 10-11 $\mu \mathrm{m}$, antibothridial 8-9 $\mu \mathrm{m}$ ), but Dollfus (1960) described two additional varieties, one of them 1.9 mm long. Previous studies (Palm et al. 1997, Palm 1999, 
Palm and Walter 1999) demonstrated that intraspecific variability can be high in tentaculariids, and Palm and Walter (2000) synonymised several Heteronybelinia species with $H$. estigmena (Dollfus, 1960). Palm (1995) already described this species (as $H$. alloiotica) from the coastal waters off Ocean Springs. Thus, on basis of a single postlarva, we prefer tentatively to consider the species Heteronybelinia cf. estigmena.

Heteronybelinia palliata (Linton, 1924) comb. n.

Figs. 3-8

Redescription (based on three adult syntypes of Tetrarhynchus palliatus Linton, 1924 from Sphyrna zygaena (Linnaeus) [USNPC 7726], one with invaginated tentacles): Scolex craspedote, 1621 (1472-1856) SL with velum (Fig. 3), 828 (715-1040) SW, 763 (715-806) pbo, 650 (519-780) pv, 377 (351-392) pb, 615 (533-676) vel, 335 (277-368) BL, 144 (140-147) BW; BR 2.3 (1.9:12.6:1); SP 2.0:1.7:1 (2.3:2.2:1, 1.8:1.3:1, 2.0:1.7:1). Tentacles with basal swelling lacking $(\mathrm{n}=2), 300-420 \mathrm{TL}$, 30-32 TW (basal), 33-33 TW (metabasal), 33-33 TSW, with prebulbular organs and muscular rings around tentacle sheaths lacking, with retractor muscle inserting in basal part of bulb. Tentacular armature homeoacanthous, heteromorphous (Fig. 4), with hooks of similar size and of different shape on internal and external tentacle surfaces $(\mathrm{n}=2)$; hooks on internal surface compact and rosethornshaped, 17-18 L, 14.0-15.5 B, diminishing in size (Fig. 5) toward basal part of tentacle to $12.5-14.0 \mathrm{~L}, 9.0-10.5 \mathrm{~B}$; hooks on external surface more slender and spiniform than those on internal surface, 16.5-18.0 L, 8.5-10.0 B, diminishing in size towards basal part of the tentacle to 12.5-14.0 L, 6-8 B; hsr 6-7 (basal), 6-7 (metabasal).

Strobila $(\mathrm{n}=3)$ craspedote, consisting of 71,80 and 108 proglottids, with about 20 of those proglottids overlapped by velum of scolex. Proglottids wider than long (Figs. 6, 7), with size increasing continuously; with proglottis $40=140 \times 950,80 \times 900,70 \times 1260$, with proglottis $70=350 \times 1900,250 \times 1270,330 \times 1970$, and with proglottis $100=670 \times 2270,400 \times 1840$. Testes in proglottis 70 numbering 60-70, in several layers, 40-80 in diameter, relatively large and ovoid around female genital complex, smaller and oval-shaped along margin of proglottid, with some present anterior to cirrus sac; cirrus sac elongate, 530-600 long, 65-80 wide, thin-walled, directed anteriomedially from genital atrium; cirrus unarmed, 750-800 long, with internal and external seminal vesicles not evident; genital atrium ventro-submarginal in anterior third of proglottid, alternating irregularly. Ovary bilobed. Further details of the reproductive organs are given by Linton (1924, p. 96).

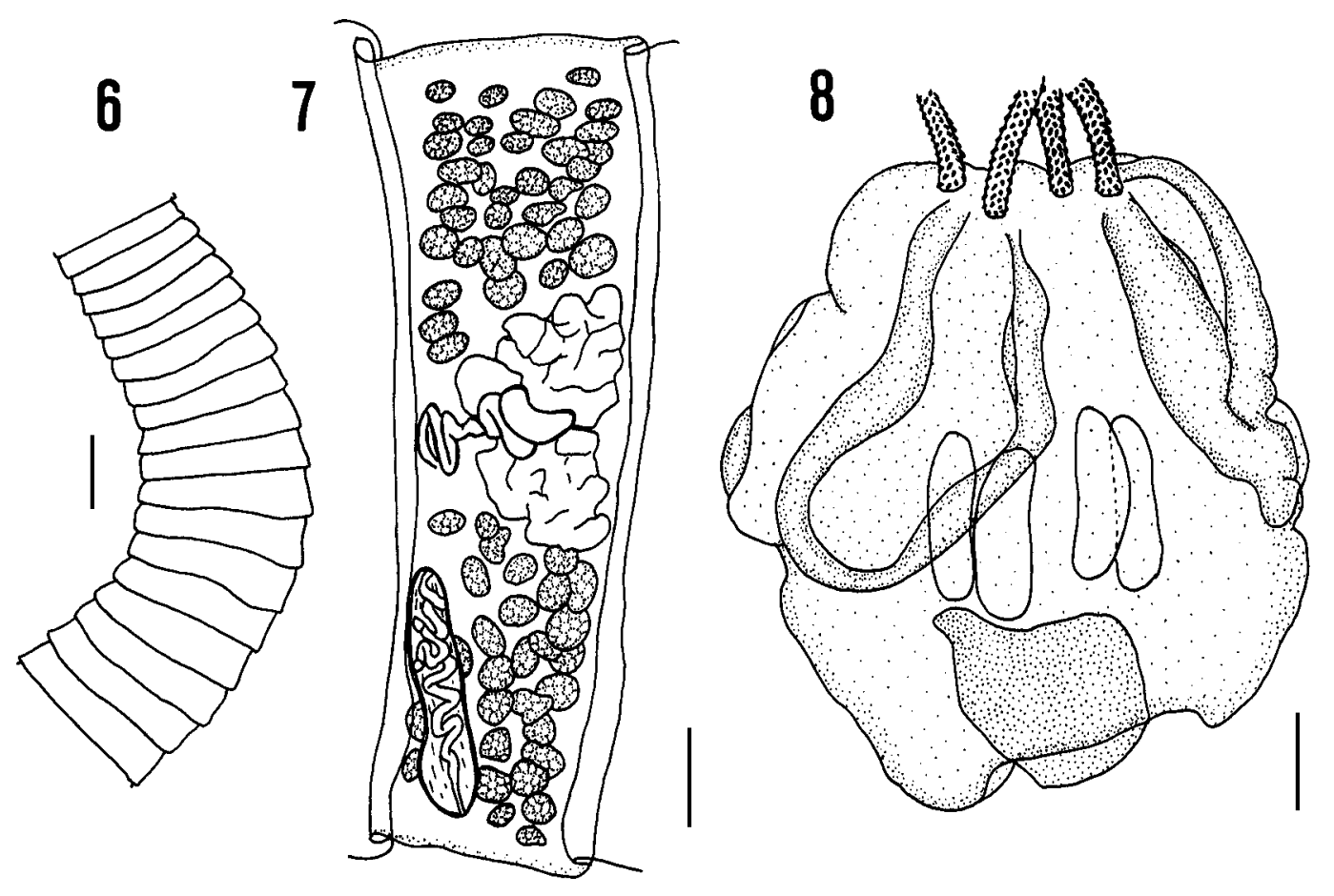

Figs. 6-8. Heteronybelinia palliata. Fig. 6. Strobila between the 45 th and 62 nd proglottids behind the velum. Fig. 7. Mature proglottid. Fig. 8. Postlarva isolated from Paralichthys dentatus. Scale bars: Fig. $6=1 \mathrm{~mm}$; Figs. 7, $8=200 \mu \mathrm{m}$. 
Supplemental data (based on two postlarvae from Paralichthys dentatus (Linnaeus), USNPC 80723): Scolex craspedote (Fig. 8), 1489 (1378-1600) SL with velum, 1170 SW, 930 (923-936) pbo, 748 (624-871) pv, 406 (387-424) pb, 443 (325-520) vel, 350 (300-400) app, 373 (360-386) BL, 110 (106-114) BW; BR 3.4:1; SP 2.4:2.3:1 / 2.2:1.5:1. Tentacle with basal swelling lacking, 450-500 TL, 33-39 TW (basal), 20-33 TW (metabasal), 16 TSW, prebulbular organs and muscular rings around tentacle sheaths lacking; retractor muscles inserting into basal part of bulbs; hooks on internal tentacle surface compact and rosethorn-shaped, 17.5-19.0 L, 13.5-15.0 B, diminishing in size toward basal part of tentacle to $13.0-14.5 \mathrm{~L}, 9.0-$ $10.5 \mathrm{~B}$; hooks on external surface more slender and spiniform than internal ones, 18.0-19.5 L, 8.5-10.0 B, diminishing in size toward basal part of tentacle to 13-14 $\mathrm{L}, 6.5-8.0 \mathrm{~B}$; basal armature similar to metabasal armature in hook form and pattern, with hsr 6-7 (basal), 6-7 (metabasal).

M a t e r i a 1 e x a m i n e d : syntypes - USNPC 7726, E. Linton coll., 19.07.1915, 5 adults from the stomach wall of $S$. zygaena, Woods Hole, Massachusetts (MA), USA; other material, labelled as Nybelinia bisulcata - USNPC 35764, MacCallum coll., 02.07.1915, 4 adults from the stomach wall of S. zygaena, Woods Hole, MA; USNPC 80723, 1980, 3 postlarvae from $P$. dentatus, Chesapeake Bay, Virginia, USA.

Remarks: Chandler (1942) reported Nybelinia palliata from the smooth hammerhead, Sphyrna zygaena, in the Gulf of Mexico; however, we could not locate his material at the USNPC or elsewhere. Nevertheless, we obtained syntype material, which was from the same host species at Woods Hole but not adequately described, and we redescribed it. Linton (1924) described $N$. palliata as having hooks nearly uniform in size and shape, however, he did not comment on the hook shape on different tentacle surfaces. Linton (1924, fig. 82) illustrated the tentacular armature, however, it is not possible to distinguish between hook forms on opposite tentacle surfaces on basis of his illustration. Re-examination of the syntypes (see above) revealed two distinct hook forms on opposite tentacle surfaces, belonging to the homeoacanths type II as given by Campbell and Beveridge (1994). Thus, we accept Nybelinia palliata as a valid species, however, our present description of heteromorphous tentacular hooks assigns it to the genus Heteronybelinia as described by Palm (1999). Palm et al. (1997) assigned N. palliata to Nybelinia subgroup IAa and Palm (1999) to the genus Nybelinia, erroneously interpreting the hooks on basis of Linton's description as having a homeomorphous armature. We now consider the species to belong to the genus Heteronybelinia Palm, 1999 as Heteronybelinia palliata (Linton, 1924) comb. n.

The characteristic tentacular armature with hooks of similar size but of different shape on opposite tentacle surfaces now conflicts with the identification of some material deposited as $N$. bisulcata (Linton, 1889) in the
U.S. National Parasite Collection, Beltsville (specimens USNPC 35764 and 80723). Based on features of those specimens, they are conspecific with $H$. palliata. The tentacular armature was identical, and scolex measurements overlapped. However, even though the scolex proportions correspond, the bulb ratio differed between adult (1.9-2.6:1) and postlarval (3.4:1) specimens.

Heteronybelinia palliata is now recognised from $S$. zygaena along the eastern North American coast (MacCallum 1921, Linton 1924) and the Gulf of Mexico (Chandler 1942). The summer flounder, Paralichthys dentatus, represents a new intermediate host record for $H$. palliata in Chesapeake Bay, where Jansen and Burreson (1990) reported a prevalence of the species as $N$. bisulcata to be $11 \%$ (341 fish examined).

\section{Other plerocercoids from the northern Gulf of Mexico} in or adjacent to Mississippi

- Callitetrarhynchus gracilis (Rudolphi, 1819) from the mesentery of *Arius felis (Linnaeus), *Elops saurus (Linnaeus), *Lutjanus campechanus (Poey), *Scomberomorus cavalla (Cuvier) and S. maculatus (Mitchill);

- Dasyrhynchus pacificus Robinson, 1965 from *Mugil curema Valenciennes and *Mugil cephalus Linnaeus. Details of the scolex of a specimen from M. curema are given in Figs. 9-12. The specimen shows an elongated pars vaginalis with short bulbs, which is not corresponding directly to the description of Dasyrhynchus pacificus by Beveridge and Campbell (1993, fig. 6). However, the tentacular armature appeared to be the same.

- Otobothrium cysticum (Mayer, 1842) from the mesentery of *Arius felis, *Caranx crysos (Mitchill), *Lutjanus campechanus and *Paralichthys lethostigma Jordan et Gilbert;

- Tentacularia coryphaenae Bosc, 1797 from the mesentery of * Rachycentron canadum (Linnaeus);

- Gymnorhynchus gigas (Cuvier, 1817) Rudolphi, 1819 from musculature of *Brama brama (Bonnaterre) (from an unspecified location of Florida, provided by NMFS Seafood Inspection Laboratory in Pascagoula, Mississippi).

Remarks: Species indicated above by an asterisk (*) represent new host records. Dasyrhynchus pacificus has been recorded from the Pacific and South-West Atlantic Ocean (Beveridge and Campbell 1993). This is its first record from the Gulf of Mexico, but the identification should be corroborated with adult material. The illustration labelled as ?Callitetrarhynchus sp. from the kidney of Mugil cephalus by Overstreet (1978a, fig. 122) shows a specimen from the same plerocercoid material. The species identified as Dasyrhynchus sp. from the musculature, especially in the dorsum of the head, of Caranx hippos (Linnaeus) (crevalle jack) in fig. 120 of Overstreet (1978a) is D. giganteus, also reported from Brazil from the same host by Sao Clemente et al. (1993) and Palm (1997b). 

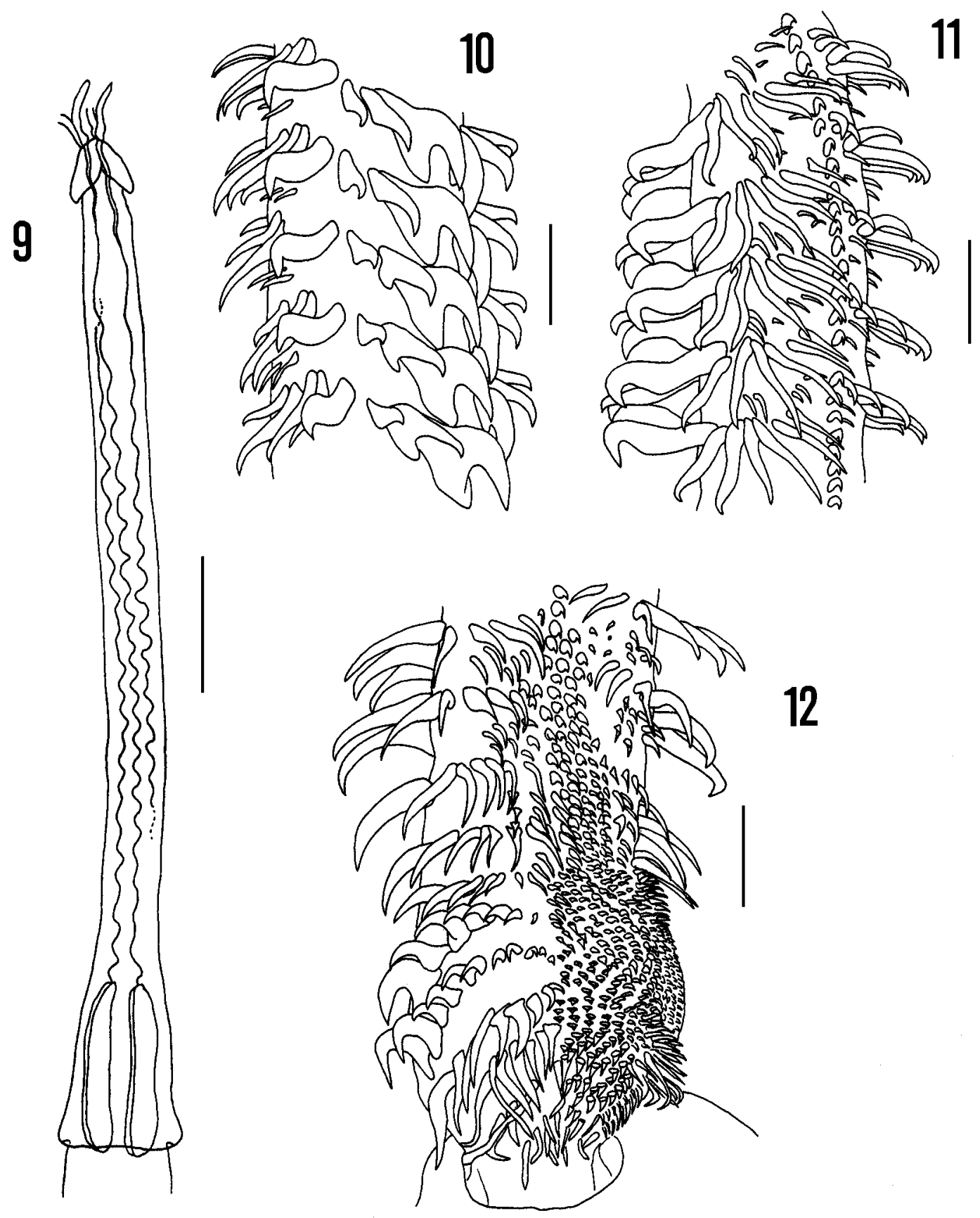

Figs. 9-12. Dasyrhynchus pacificus from Mugil curema. Fig. 9. Scolex. Fig. 10. Metabasal armature, internal surface. Fig. 11. Metabasal armature, antibothridial surface. Fig. 12. Basal armature, external surface. Scale bars: Fig. $9=1$ mm; Figs. 10-12=50 $\mu \mathrm{m}$.

\section{Other adult trypanorhynchs}

A series of 19 specimens of the blacktip shark, Carcharhinus limbatus (Valenciennes), from off Mississippi and off Sarasota, Florida, was examined for parasites. The shark hosted adult specimens of Heteronybelinia estigmena (Dollfus, 1960), Nybelinia lingualis (Cuvier, 1817), Nybelinia cf. bisulcata (Linton, 1889), Callitetrarhynchus gracilis (Rudolphi, 1819), Oto- bothrium insigne Linton, 1905, and Grillotia perelica Shuler, 1938.

Remarks: All the species collected from $C$. limbatus were found off Florida, and all but $N$. lingualis and $O$. insigne also occurred off Mississippi. Of these, all but $H$. estigmena are new host records for that shark, and $N$. cf. bisulcata is a range extension into the Gulf of Mexico. That species, however, is in need of a critical revision as 
what is called $N$. bisulcata seems to represent a complex of more than one species as indicated by our treatment of H. palliata.

\section{DISCUSSION}

The number of trypanorhynchs in the Gulf of Mexico, indicated here as 34 of about 220 confirmed species or roughly $15 \%$, is presumably low. Based on the junior author's field observations, few of the many intermediate hosts have been reported. Many of the plerocercoids in crustaceans, molluscs, and fishes have not yet been identified, and adults from many elasmobranchs have not yet been studied and taxonomically evaluated. For example, from 19 blacktip sharks recently examined over a relatively short period, we found six trypanorhynch species, and all but one had not been reported previously from that shark. Moreover, that host, Carcharhinus limbatus, is cosmopolitan and probably serves as a host for many other species. Not counting reported species of Otobothrium and Nybelinia/Heteronybelinia (see Palm 1999), we did not encounter in the blacktip shark, Poecilancistrum caryophyllum, reported as $P$. robustum by Thatcher (1961) from Louisiana, Dasyrhynchus pacificus, reported by Beveridge and Campbell (1993) from Rio de Janeiro, Brazil, nor did we encounter Tentacularia coryphaenae, Floriceps saccatus, or Dasyrhynchus giganteus reported by Heinz and Dailey (1974) and Carvajal et al. (1976) from the Pacific Ocean. The latter three species also either already have been reported from or are expected to occur in the Gulf of Mexico. However, the specimens from Hawaii reported as D. giganteus were immature and when re-examined by Beveridge and Campbell (1993), the authors suggested the specimens were D. variouncinatus (Pintner, 1913) because a mature specimen of that species occurred in Carcharhinus falciformis (Bibron) (silky shark) off Hawaii. All records of $D$. variouncinatus from the Atlantic Ocean (see Dollfus 1969) were considered by Beveridge and Campbell (1993) to represent $D$. giganteus.

As indicated above, the low estimate of 34 trypanorhynchs recorded from the Gulf of Mexico still makes the Gulf of Mexico one of the richest known regions for trypanorhynchs in the world (four species are newly recorded from the Gulf of Mexico within the present study). The Gulf of Mexico can be characterised as a relatively shallow-water marine system, and most of the specimens we examined were from near-shore species or from fish that had migrated to near shore. Shallow-water tropical habitats have been demonstrated to be a common locality for trypanorhynch cestodes that occur as plerocercoids in fishes from both, inshore and offshore waters, such as Grillotia perelica (see Schramm 1991), Callitetrarhynchus gracilis (see Palm 1997b) and Otobothrium cysticum (see Palm et al. 1994, Palm and Overstreet 2000). This indicates that the rich, relatively warm and shallow nearshore localities provide a suitable habitat for many different trypanorhynchs. Beside a species-rich intermediate and final host fauna within the Gulf, the Gulf of Mexico water also interfaces with the Atlantic Ocean. Thus, oceanic fish species, such as the common dolphin fish, Coryphaena hippurus, and the cobia, Rachycentron canadum, allow cosmopolitan trypanorhynchs (e.g., T. coryphaenae) to spread into the Gulf of Mexico.

The presence of Kotorella pronosoma from the Gulf of Mexico demonstrates a cosmopolitan distribution for the species, as indicated by Palm and Walter (1999). Cynoscion nebulosus is the first known second intermediate host for the species. With emendation of the generic diagnosis, we corroborate the placement of Kotorella within Tentaculariidae. Beveridge et al. (1999) discussed the phylogenetic relationship between Kotorella and Nybelinia. The bothridia of the present metacestodes have similarities to both tentaculariid and nontentaculariid trypanorhynchs. The large bothridia with free posterior margins, overlapping half the scolex, resemble those described for Bombycirhynchus sphyraenaicum (see Pintner 1930, Palm et al. 1998). Similarly, free posterior margins are characteristic for members of lacistorhynchid genera, such as Callitetrarhynchus and Pseudolacistorhynchus (see Dollfus 1942, Palm 1995). These genera additionally have characteristic marginal bands of microtriches (Palm 1995). If these structures could be considered homologous characters, they would be useful for future trypanorhynch classifications. Kotorella pronosoma can also be considered as a species with individuals having a large range in size. Length of plerocercoid scolex ranges from 650 to $1000 \mu \mathrm{m}$, and, depending on the scolex size, hooks vary from 8 to $14 \mu \mathrm{m}$ in length. This species further demonstrates the remarkable variability that can occur within a tentaculariid species, as earlier observed (Palm et al. 1993, 1997, Palm 1999, Palm and Walter 1999, 2000).

The difference in bulb ratio between adult $(2.3: 1)$ and postlarval $(3.4: 1)$ specimens of Heteronybelinia palliata demonstrates a problem in identifying some tentaculariids. Dollfus (1960) showed a range in bulb ratio of postlarvae of Nybelinia africana $(2.7: 1$ to $3.1: 1)$. Consequently, at least in a species of both Heteronybelinia and Nybelinia, the ratio can vary up to $50 \%$. This difference questions the usage of the ratio as a primary diagnostic feature, such as used by Dollfus (1960) to separate Nybelinia alloiotica, $N$. cadenati and $N$. senegalensis from $N$. dakari, $N$. estigmena and N. punctatissima. Palm (1999) already discussed the similarity of several species within a species complex of " $N$. aequidentata" and another species complex of " $H$. estigmena". This explains our difficulty to identify Nybelinia cf. estigmena in the present study. Moreover, Jones and Beveridge (1998) pointed out that requisite information to differentiate many of the 47 nominal species of Nybelinia is not available. 
In conclusion, the Gulf of Mexico serves as a rich habitat for trypanorhynchs, and some of these have a high intraspecific morphological variability, often combined with both a wide host range and a wide zoogeographical distribution. Whether differences in scolex features depend on age, stage of development, host, geographic locality or a combination of factors cannot be determined at present; however, the reason for these differences needs to be considered for future trypanorhynchean taxonomic work. We recommend that identifications based on minor size differences in structures such as hook size should be treated with care until inter- and intraspecific morphological variability is clarified.
Acknowledgements. Financial support was provided by the German Research Council, DFG Mo 395/3-1 and PA 664/3-1; USDA, CSREES, Award No. 98-38808-6019; NOAA, NMFS, Award No. NA86FL0476; and EPA and Gulf of Mexico Program Award No. MX994732-95-0. We extend our thanks to Dr. I. Beveridge, University of Melbourne, and Dipl. Biol. T. Walter, University of Kiel, for comments on an earlier draft of the manuscript. We also thank Ronnie Palmer, Tom Mattis, Nate Jordan, and others at GCRL plus Bob Hueter, M. Henry and others at Mote Marine Laboratory, Sarasota, Florida, for technical assistance regarding hosts or parasites.

\section{REFERENCES}

ALDRICH D.V. 1965: Observations on the ecology and life cycle of Prochristianella penaei Kruse (Cestoda: Trypanorhyncha). J. Parasitol. 51: 370-376.

BEVERIDGE I., CAMPBELL R.A. 1993: A revision of Dasyrhynchus Pintner (Cestoda: Trypanorhyncha), parasitic in elasmobranch and teleost fishes. Syst. Parasitol. 24: 129157.

BEVERIDGE I., CAMPBELL R.A., PALM H.W. 1999: Preliminary cladistic analysis of genera of the cestode order Trypanorhyncha Diesing, 1863. Syst. Parasitol. 42: 29-49.

CAKE E. 1977: Larval cestode parasites of edible molluscs of the northeastern Gulf of Mexico. Gulf Res. Rep. 6: 1-8.

CAMPBELL R.A., BEVERIDGE I. 1994: Order Trypanorhyncha Diesing, 1863. In: L.F. Khalil, A. Jones and R.A. Bray (Eds.), Keys to the Cestode Parasites of Vertebrates. CAB International, Wallingford, pp. 51-148.

CARVAJAL J., CAMPBELL R.A., CORNFORD E.M. 1976: Some trypanorhynch cestodes from Hawaiian fishes, with descriptions of four new species. J. Parasitol. 62: 70-77.

CHANDLER A.C. 1942: Some cestodes from Florida sharks. Proc. U. S. Nat. Hist. Mus. 92: 25-31.

CHANDLER A.C. 1954: Cestoda. In: Fish and Wildlife Service, U.S. Department of the Interior (Ed.), Gulf of Mexico, its Origin, Waters, and Marine Life. Fish. Bull. Fish Wildlife Serv. 55: 351-353.

DOLLFUS R.P. 1942: Études critiques sur les Tétrarhynques du Muséum de Paris. Arch. Mus. Hist. Nat. Paris 19: 1-466.

DOLLFUS R.P. 1960: Sur une collection de Tétrarhynques homéacanthes de la famille des Tentaculariidae recoltées principalement dans la région de Dakar. Bull. Inst. Fr. Afr. Noire, Sér. A 22: 788-852.

DOLLFUS R.P. 1969: Quelques espèces de cestodes Tétrarhynques de la côte Atlantique des États Unis, dont l'une n'était pas connue à l'état adulte. J. Fish. Res. Board Can. 26: 1037-1061.

EUZET L., RADUJKOVIC B.M. 1989: Kotorella pronosoma (Stossich, 1901) n. gen., n. comb., type des Kotorellidae, nouvelle famille de Trypanorhyncha (Cestoda), parasite intestinal de Dasyatis pastinaca (L., 1758). Ann. Parasitol. Hum. Comp. 64: 420-425.

FEIGENBAUM L.F. 1975: Parasites of the commercial shrimp Penaeus vannamei Boone and Penaeus brasiliensis Latreille. Bull. Mar. Sci. 25: 491-514.
HEINZ M.L., DAILEY M.D. 1974: The Trypanorhyncha (Cestoda) of elasmobranch fishes from southern California and northern Mexico. Proc. Helminthol. Soc. Wash. 41: 161169.

HENSON R.N. 1975: Cestodes of elasmobranch fishes of Texas. Texas J. Sci. 26: 401-406.

HILDRETH M.B., LUMSDEN R.D. 1985: Description of Otobothrium insigne plerocercus (Cestoda: Trypanorhyncha) and its incidence in catfish from the Gulf of Louisiana. Proc. Helminthol. Soc. Wash. 52: 44-50.

JANSEN M.E., BURRESON E.M. 1990: Parasites of summer flounder, Paralichthys dentatus, in the Chesapeake Bay. J. Helminthol. Soc. Wash. 57: 31-39.

JONES M.K., BEVERIDGE I. 1998: Nybelinia queenslandensis sp. n. (Cestoda: Trypanorhyncha) parasitic in Carcharhinus melanopterus, from Australia, with observations on the fine structure of the scolex including the rhyncheal system. Folia Parasitol. 45: 295-311.

KRUSE D.N. 1959: Parasites of the commercial shrimps, Penaeus aztecus Ives, $P$. duorarum Burkenroad and $P$. setiferus (Linnaeus). Tulane Stud. Zool. 7: 123-144.

LINTON E. 1924: Notes on cestode parasites of sharks and skates. Proc. U. S. Nat. Hist. Mus. 64: 1-114.

MacCALLUM G.A. 1917: Some new forms of parasitic worms. Zoopathologica 1: 43-75.

MacCALLUM G.A. 1921: Studies in helminthology, Part 2: Cestoda. Zoopathologica 1: 205-254.

NIKOLAEVA V.M., PARUHIN A.M. 1968: To the study of fish helminths in the Gulf of Mexico Mater. Sov. Kubin. Morsk. Eksped. 2, pp. 126-149. (In Russian.)

OVERSTREET R.M. 1977: Poecilancistrium caryophyllum and other trypanorhynch cestode plerocercoids from the musculature of Cynoscion nebulosus and other sciaenid fishes in the Gulf of Mexico. J. Parasitol. 63: 780-789.

OVERSTREET R.M. 1978a: Marine Maladies? Worms, Germs, and Other Symbionts from the Northern Gulf of Mexico. Miss.-Ala. Sea Grant Consortium, MASGP-78-021, 140 pp.

OVERSTREET R.M. 1978b: Trypanorhynch infections in the flesh of sciaenid fishes. Mar. Fish. Rev. 40: 37-38.

PALM H.W. 1995: Untersuchungen zur Systematik von Rüsselbandwürmern (Cestoda: Trypanorhyncha) aus Atlantischen Fischen. Berichte aus dem Institut für 
Meereskunde an der Christian-Albrechts-Universität Kiel. No. 275, 238 pp.

PALM H.W. 1997a: An alternative classification of trypanorhynch cestodes considering the tentacular armature as being of limited importance. Syst. Parasitol. 37: 81-92.

PALM H.W. 1997b: Trypanorhynch cestodes from commercial fishes from North-East Brazilian coastal waters. Mem. Inst. Oswaldo Cruz 92: 69-79.

PALM H.W. 1999: Nybelinia Poche, 1926, Heteronybelinia gen. nov. and Mixonybelinia gen. nov. (Cestoda: Trypanorhyncha): in the collections of The Natural History Museum, London. Bull. Nat. Hist. Mus. Lond. (Zool.) 65: 133-153.

PALM H.W., MÖLLER H., PETERSEN F. 1993: Otobothrium penetrans (Cestoda; Trypanorhyncha) in the flesh of belonid fish from Philippine waters. Int. J. Parasitol. 23: 749-755.

PALM H.W., OBIEKEZIE A.I., MÖLLER H. 1994: Trypanorhynchid cestodes of commercial inshore fishes of the West African coast. Aquat. Living Resour. 7: 153-164.

PALM H.W., OVERSTREET R.M. 2000: Otobothrium cysticum (Cestoda: Trypanorhyncha) from the muscle of butterfishes (Stromateidae). Parasitol. Res. 86: 41-53.

PALM H.W., POYNTON S.L., RUTLEDGE P. 1998: Surface ultrastructure of Bombycirhynchus sphyraenaicum (Pintner, 1930) (Cestoda: Trypanorhyncha). Parasitol. Res. 84: 195204.

PALM H.W., WALTER T. 1999: Nybelinia southwelli sp. nov. (Cestoda: Trypanorhyncha) with the re-description of $N$. perideraeus (Shipley and Hornell, 1906) and synonymy of N. herdmani (Shipley and Hornell, 1906) with Kotorella pronosoma (Stossich, 1901). Bull. Nat. Hist. Mus. Lond. (Zool.) 65: 123-131.

Received 3 July 1999
PALM H.W., WALTER T. 2000: Tentaculariid cestodes (Trypanorhyncha) from the Muséum national d'Histoire naturelle, Paris. Zoosystema 22: 641-666.

PALM H.W., WALTER T., SCHWERDTFEGER G., REIMER L.W. 1997: Nybelinia Poche, 1926 (Cestoda: Trypanorhyncha) from the Moçambique coast, with description of $N$. beveridgei sp. nov. and systematic considerations of the genus. South Afr. J. Mar. Sci. 18: 273-285.

PINTNER T. 1930: Wenigbekanntes und Unbekanntes von Rüsselbandwürmern. Sitzungsber. Math. Naturwiss. Kl. Abt. I 139: 445-537.

SAO CLEMENTE S.E., MATOS E., UCHOA C.M.A. 1993: Trypanorhynch plerocerci in fish of commercial importance in Brazil. Parasitol. al Día 17: 52-53.

SCHLICHT F.G., McFARLAND W.N. 1967: Incidence of trypanorhynchan plerocercoids in some Texas coast sciaenid fishes. Contr. Mar. Sci. Biol. 12: 101-112.

SCHRAMM M. 1991: Grillotia perelica (Cestoda: Trypanorhyncha) plerocercoids in mullet (Pisces: Mugilidae) from estuaries in Transkei, Southern Africa. South Afr. J. Mar. Sci. 11: 169-178.

SHIPLEY A.E., HORNELL F.L.S.. 1906: Report on the cestode and nematode parasites from the marine fishes of Ceylon. Report to the Government of Ceylon on the Pearl Oyster Fisheries of the Gulf of Manaar, Part 5, pp. 43-96.

THATCHER V.E. 1961: Studies of the Cestoda of elasmobranch fishes of the northern Gulf of Mexico. Part I. Proc. La. Acad. Sci. 23: 65-74.

VIJAYALAKSHMI C., VIJAYALAKSHMI J., GANGADHARAM T. 1996: Some trypanorhynch cestodes from the shark Scoliodon palasorrah (Cuvier) with the description of a new species, Tentacularia scoliodoni. Riv. Parassitol. 13: 83-89.

Accepted 26 April 2000 